J. Environ. Sci.

Institute of Environmental Studies and Research - Ain Shams University

\title{
COMPARISON BETWEEN DIFFERENT TISSUES USING INNOVATED METHODS IN EXTRACTION OF DNA FOR IDENTIFICATION OF CORPSE IN CASE OF ENVIRONMENTAL DISASTERS, EXPLOSIONS AND FIRES
}

\begin{abstract}
Jihan A. Abd Elwahab ${ }^{(1)}$; Sherien S. Ghaleb ${ }^{(2)}$ and Mostafa H. Ragab ${ }^{(3)}$

1) Egyptian Forensic Medicine Authority- DNA-Ministry of Justice 2) Department of Forensic Science, Cairo University 3) Department of Environmental Medical sciences, Institute of Environmental Studies and Researches, Ain Shams University
\end{abstract}

\begin{abstract}
Introduction: Every disaster is unique and involves interplay of different factors and circumstances such as nature of disaster, number of victims and extent of body fragmentation that ultimately challenges the disaster response planning. Sample preference for DNA analysis can help in proper management of the disaster. Since a disaster is a chaotic environment that can complicate effective identification of the remains. With some planning, and proper sample selection we can reduce stress for those involved in the identification process thus increasing the probability that all recovered samples are identified.

Aim of the Work: To recognize and decide which human tissue is preferred over the other for DNA tests for human identification for available samples saved from different environmental disasters .Therefore we can decide which sample is preferred over the other if available., Based on the DNA yield obtained from different human tissues.

Materials and Methods: This cross sectional laboratory based study was conducted at the Egyptian Forensic Medicine Authority (EFMA) at Sayda
\end{abstract}


Zaynab. From May 2016 to April 2017 and tested using manual Qiagen extraction kit or Qiagen automated kit using EZ1.

Extracted DNA was then quatified using Quatifiler® Human DNA Quatification kit by Step one Real Time PCR.

Samples were amplified using AmpFlSTR R Identifiler $\mathrm{R}$ plus PCR Amplification Kit (Life Technologies Applied Biosystems). Amplified PCR products were run electrophorethically on a 3130xl or 3500 Genetic Analyzer (Life Technologies Applied Biosystems)

Results: Comparison between different tissues recovered from the site of different disasters showed that dry blood stain have better DNA(Deoxyribonucleic acid) yield and STR(Short Tandem Repeat ) results followed by fresh tissue. Moreover cartilage samples are preferable to bone samples concerning DNA yield and STR results. Finally skin followed by teeth had the least DNA yield.

Conclusion: During sample selection of collected tissue parts and fragments it is preferable to get a dry blood sample if available, if not try to select fresh muscle tissue if not available search for hair with roots then selection of cartilage gave better results than bone concerning DNA yield and STR results leaving skin then teeth as the last choice.

Keywords: Disasters, human remains, human identification, DNA yield, STR, tissues.

\section{INTRODUCTION}

The nature of mass disaster events means that bodies have often been exposed to extreme conditions such as fire, immersion in water for long periods, explosion, or crushing force from debris, prior to the collection of the samples. Under these conditions, soft tissue, blood, bones ,cartilage , teeth and hair are susceptible to damage and DNA extraction from these media can very quickly become problematic. However they may be the only substrate from which DNA may be obtained for identification. The physical and chemical properties that make them resistant to degradation can make the DNA within them difficult to extract. Although the strength of bones and 
teeth, exposure to adverse conditions in a mass disaster can still damage and degrade their DNA, making it more dicult to extract enough quality DNA to form a full short tandem repeat (STR) profile ( Pagana et al, 2012).

In disaster victim identification (DVI), DNA profiling is considered to be one of the most reliable and efficient means to identify bodies or separated body parts. This needs a post mortem DNA sample, and an ante mortem DNA sample of the presumed victim or their biological relative(s). The collection of an adequate ante mortem sample is technically simple, but the acquisition of a good quality post mortem sample under unfavorable DVI circumstances is complicated due to the variable degree of preservation of the human remains (De Boer et al, 2018 a).

The extraction of DNA from tissue samples and the comparison of DNA profiles is presently mostly standardized, automated and digitalized. Optimized procedures enable high- volume throughput and facilitate the collection and comparison of DNA profiles from different laboratories and countries thus setting a strategy for sample collection (Montelius and Lindblom, 2012).

The aim of this work is to compare between different results concerning quantity of DNA yield from various samples of different body parts and to evaluate and prioritize the samples as regard their ability to preserve DNA in spite of environmental disasters. In a way so we can put a strategy for sample selection in different disaster events and considering which tissue to select for samples recovered from disaster site thus reducing test time, cost and sample repetition therefore we can identify samples in the nearest time space and maximize the probability that all victims are identified and deliver bodies or 
body parts to their relatives so they can bury them morn for them out of respecting and recognizing the emotional needs of the victims' families and friends.

\section{MATERIALS AND METHODS}

This cross sectional study was conducted at the Egyptian Forensic Medicine Authority (EFMA) at Sayda Zaynab, from May 2016 to April 2017. Different samples from 3 separate accidents were collected .Reference Samples from relatives were collected (blood or buccal swabs) or victim's ante mortum. Samples to be tested included dry blood stains (or swabs), tissue (e.g muscle or tendons) ,bone, cartilage, teeth, skin and hair .

1-Testing 229 samples recovered from an air craft crash leaving 63 victims 61 of them were identified

2-Testing 7 samples recovered from a fire in an oil factory leaving 4 victims 3 of them were identified

3-Testing 10 samples recovered from an explosion leaving 9 victims, all were identified.

\section{Inclusion criteria:}

- Samples recovered from bodies, body parts or body fragments including bone, cartilage, dried blood stain on gauze or swabs ,teeth, tissue (e.g: muscle, tendons),skin and hair.

- Samples subjected to varying degrees of burns, putrefaction or drowning obtained in cases of disasters, burns or explosion. Preserved dry at room temperature or in saline and freeze at $-20{ }^{\circ} \mathrm{C}$ to $-40{ }^{\circ} \mathrm{C}$ 
-Age: any age

-Sex: both sexes

\section{Exclusion criteria:}

-Corpses not subjected to any accidents that may affect the integrity of the DNA

-Disasters or events outside Egypt

Methods: Samples are processed and prepared before extraction according to the nature of the sample (e.g. cutting, grinding and decontamination). Then every sample supplied undergoes the following investigations:

*DNA Extraction: Genomic DNA will be extracted using QIA amp DNA minikit by QIAGEN or automatic extractor EZ1.

* PCR: Extracted DNA will be amplified according to manufacture instructions using AmpFl STR ${ }^{\circledR}$ IdentifilerTM PCR (Polymerase chain reaction) amplification kit.

*Quantification: quantification of the amount of DNA using Quatifiler () Human DNA Quantification kit by Step one Real Time PCR.

*Typing: The PCR product will be detected using the Genetic Analyzer for 15core STR loci as well as the amelogenin (sex determining) and Y-STR profile for selected samples.

*Interpretation: of the results of samples and reference samples or relatives to the reference allelic ladder included in the kit to determine the matching to reference samples. 


\section{Statistical Methods:}

Data were analyzed using IBM@ SPSS@ Statistics version 23 (IBM@ Corp., Armonk, NY) and JMP® Version 13.2.1 (SAS@ Institute Inc., Cary, $\mathrm{NC})$.

Skewed numerical data were presented as median and interquartile range and intergroup differences were compared using Kruska Wallis test. The Dunn tets was used for post hoc comparisons with application of the Bonferroni correction to adjust the critical $\mathrm{p}$-value for the number of pairwise comparisons.

\section{RESULTS}

Table 1. DNA yield from various types of tissues examined in an explosion disaster

\begin{tabular}{|c|c|c|c|c|c|c|c|c|}
\hline & \multicolumn{7}{|c|}{ DNA yield (ng/100 mg/ $\mathbf{\mu l})$} \\
\hline \hline $\begin{array}{c}\text { Tissue } \\
\text { type }\end{array}$ & Count & Min & Max & Mean & SD & $\begin{array}{c}25^{\text {th }} \\
\text { percentile }\end{array}$ & Median & $\begin{array}{c}75^{\text {th }} \\
\text { Percentile }\end{array}$ \\
\hline $\begin{array}{c}\text { Cartil- } \\
\text { age }\end{array}$ & 3 & 26 & 19.35 & 10.76 & 9.69 & .26 & 12.68 & 19.35 \\
\hline Bone & 1 & 9.0 & 9.00 & 9.00 & - & 9.00 & 9.00 & 9.00 \\
\hline Tissue & 6 & 2.2 & 14.47 & 5.91 & 4.96 & 2.20 & 3.74 & 9.14 \\
\hline \hline
\end{tabular}

$\mathrm{SD}=$ standard deviation.

The table shows that in an explosion the maximum DNA yield was given by cartilage samples $10.76(\mathrm{ng} / 100 \mathrm{mg} / \mu \mathrm{l})$ followed by tissue $14.47(\mathrm{ng} / 100$ $\mathrm{mg} / \mu \mathrm{l})$ then bone samples $9.00(\mathrm{ng} / 100 \mathrm{mg} / \mu \mathrm{l})$. 
J. Environ. Sci.

Institute of Environmental Studies and Research - Ain Shams University

Table 2: DNA yield $(\mathrm{ng} / 100 \mathrm{mg} / \mu \mathrm{l})$ from various types of tissues examined in a fire disaster

\begin{tabular}{|c|c|c|c|c|c|c|c|c|}
\hline & \multicolumn{7}{|c|}{ DNA yield (ng/100 mg/ $\mathbf{\mu l})$} \\
\hline \hline $\begin{array}{c}\text { Tissue } \\
\text { type }\end{array}$ & Count & Min & Max & Mean & SD & $\begin{array}{c}25^{\text {th }} \\
\text { percentile }\end{array}$ & Median & $\begin{array}{c}75^{\text {th }} \\
\text { Percentile }\end{array}$ \\
\hline Bone & 4 & 0.00 & 0.03 & 0.01 & 0.01 & 0.00 & 0.01 & 0.02 \\
\hline Cartila-ge & 3 & 0.13 & 9.27 & 4.92 & 4.5 & 0.13 & 5.36 & 9.27 \\
\hline
\end{tabular}

$\mathrm{SD}=$ standard deviation.

The table shows that in a fire disaster the DNA yield of the cartilage samples was much higher than the of the bone samples revealing a mean of $4.92(\mathrm{ng} / 100 \mathrm{mg} / \mu \mathrm{l})$ for cartilage samples whereas $0.01(\mathrm{ng} / 100 \mathrm{mg} / \mu \mathrm{l})$ for bone samples.

Table 3. DNA yield from various types of tissues examined in a aircraft crash disaster

\begin{tabular}{|c|c|c|c|c|c|c|c|c|}
\hline & \multicolumn{7}{|c|}{ DNA yield (ng/100 mg/ $\boldsymbol{\mu l})$} \\
\hline $\begin{array}{c}\text { Tissue } \\
\text { type }\end{array}$ & Count & Min & Max & Mean & SD & $\begin{array}{c}\mathbf{2 5}^{\text {th }} \\
\text { percentie }\end{array}$ & Median & $\begin{array}{c}\mathbf{7 5}^{\text {th }} \\
\text { percent- } \\
\text { ile }\end{array}$ \\
\hline $\begin{array}{c}\text { Cartil- } \\
\text { age }\end{array}$ & 94 & 0.00 & 15.9 & 1.59 & 2.46 & 0.18 & 0.70 & 2.00 \\
\hline Bone & 98 & 0.00 & 4.01 & 0.47 & 0.77 & 0.06 & 0.16 & 0.43 \\
\hline $\begin{array}{c}\text { Dry } \\
\text { stain }\end{array}$ & 2 & 38.31 & 169.0 & 103.6 & 92.41 & 38.31 & 103.66 & 169.00 \\
\hline Skin & 10 & 0.00 & 0.04 & 0.02 & 0.01 & 0.02 & 0.02 & 0.04 \\
\hline Tissue & 16 & 0.08 & 113.6 & 32.17 & 28.47 & 12.81 & 25.87 & 44.00 \\
\hline Hair & 7 & 0.00 & 49.25 & 14.75 & 16.77 & 0.47 & 14.27 & 17.33 \\
\hline Tooth & 2 & 0.00 & 0.01 & 0.01 & 0.01 & 0.00 & 0.01 & 0.01 \\
\hline
\end{tabular}

$\mathrm{SD}=$ standard deviation.

The table shows that in this disaster dry blood stain samples gave the maximum mean DNA yield among tissues examined in a disaster whereas teeth and skin gave minimum mean DNA yield. 


\section{DISCUSSION}

Large scale disasters resulting in the fatality of tens to hundreds of thousands of people are increasingly prevalent (De Boer et al; 2018 a). Adding to the importance of putting a strategy for accurate management and selection of DNA samples.

The collection of a post mortem sample is more complicated, since mentioned guidelines do not address the challenges generally encountered during DVI (Disaster Victim Identification) operations. Complications are for instance: the highly variable degree of preservation of the human remains, and the high risk of (cross) contamination, primarily from commingling with other human remains and the sample selector skills (Interpol, 2018).

The matching of a post mortem DNA profile of an unidentified person with an ante mortem reference DNA profile of an individual of known identity or comparing DNA profiles from biological relatives a so-called comparative DNA analysis, is one of the preferred methods to identify anonymous individuals or human remains .The extraction of DNA from tissue samples and the comparison of DNA profiles is presently mostly standardized, automated and digitalized. Optimized procedures and proper sample selection enable high volume throughput and facilitate the collection and comparison of DNA profiles from different laboratories and countries. For DVI purposes, comparative DNA analysis has two basic preconditions to be met. It needs (a) high-quality non-DNA- contaminated tissue sample(s) from the victim's body or separated body part (the post mortem sample), and a non-DNA-contaminated reference sample from the presumed victim or from his/her genetic relative(s) (De Boer et al; 2018 b). 
The current study compare the DNA yield and the resultant profiles of different tissues recovered from 3 different incidents to aid in Maintaining a strategy of sample preference for DNA extraction in a way to avoid sample repetition thus saving time and money.

Preferred samples as revealed by the current study was primarily blood dry stain samples (or swabs) that gave the best DNA yield and a complete STR profile showing a mean of 103.66 DNA yield $(\mathrm{ng} / 100 \mathrm{mg} / \mu \mathrm{l})$ followed by tissue samples mostly muscle tissue or tendons 32.17 DNA yield (ng/100 $\mathrm{mg} / \mu \mathrm{l})$ Then hair samples with roots comes next 14.75 DNA yield (ng/100 $\mathrm{mg} / \mu \mathrm{l})$. Cartilage samples was followed giving 1.59 DNA yield (ng/100 $\mathrm{mg} / \mu \mathrm{l}$ ) then bone samples concerning DNA yield and STR results 0.47 DNA yield $(\mathrm{ng} / 100 \mathrm{mg} / \mu \mathrm{l})$. Skin samples gave a lower DNA yield 0.02 (ng/100 $\mathrm{mg} / \mu \mathrm{l})$ followed by tooth which gave the least DNA yield and bad STR results having a mean of $0.01(\mathrm{ng} / 100 \mathrm{mg} / \mu \mathrm{l})$. This agrees with Amanda et al. (2016) that Samples were categorized according to tissue type: bone and teeth, hair and nails, muscle, internal organs, skin, bone marrow, and other (cartilage, fat, and tendon). Thus bone marrow samples resulted in the highest DNA yields, the least DNA degradation, and greatest STR success. However, several muscle, hair, and nail samples generated higher STR success rates than traditionally harvested bone and tooth samples. A key advantage to preferentially using these tissue samples over bone (and marrow) and teeth is of human remains. Their comparative ease and speed of collection from the cadaver and processing during DNA extraction. Also the study agrees with that of $\mathrm{Yu}$ et al. (2015) revealing that according to Samples of hard tissues (37 teeth, 42 skull, 42 rib, and 39 nails) from 42 individuals 
The samples were taken from remains following forensic autopsy (from 2 days to 2 years after death). To evaluate the integrity of the nuclear DNA isolated, the percentage of allele calls for short tandem repeat profiles were compared between the hard tissues. DNA typing results indicated that until 1 month after death, any of the four hard tissue samples could be used as an alternative to teeth, allowing analysis of all of the loci. However, in terms of the sampling site, collection method and sample size adjustment, the rib appeared to be the best choice in view of the ease of specimen preparation. $\mathrm{Yu}$ data suggest that the rib could be an alternative hard tissue sample for DNA analysis .Thus agreeing with our study in that bone gave better STR results than teeth.

Results of this study was partly disagreed by Weedn and Baum (2011) in that ribs are preferred for moderately decomposed remains and long bones are preferred for older remains whereas we concluded that cartilage is a better choice in moderately decomposed tissues where it is mostly still preserved. They states that in case of extensively fragmented remains postmortem samples should be taken from red muscle agreeing with the current study as red muscle gave a mean of 32.17 DNA yield (ng/100 $\mathrm{mg} / \mu \mathrm{l})$ in comparison to bone which gave a mean of 0.47 DNA yield $(\mathrm{ng} / 100$ $\mathrm{mg} / \mu \mathrm{l})$.

Although we got good results from cartilage in charred bodies delivered from a fire in a factory 4.92(ng/100 mg/ $\mu \mathrm{l})$ DNA yield Weedn and Baum (2011) concluded that in case of charred body, samples from scraping of urinary bladder mucosa are preferable. But they agreed with the study in that they in case of fresh body, blood and swabs can be used for DNA analysis. 
Despite we did not use bladder swabs. This sample preference strategy based on the results of the present study match with Meyer (2003) who states in his article that post-mortem samples for DNA analysis were collected from cardiac blood and blood remnants, skeletal muscle tissue, urinary and gall bladder swabs. First preference was for cardiac blood and swabs from the urinary bladder. If these were not available, then samples were collected from skeletal tissues in his study of DNA based victim identification method in Kaprun cable car fire disaster. In Kaprun cable car fire disaster which occurred on November 11, 2000; 155 people were dead.

On the contrary to the results of this study that showed that cartilage had a higher DNA yield than bone Samuel et al. (2013) states that there was no difference between the amount of DNA recovered from cartilage and bone samples. Full STR profiles were obtained from all bone and cartilage samples.

\section{CONCLUSION}

From this study it can be concluded that with increased prevalence of disasters and accidents we need to augment the important implementation of a strategy for sample preference concerning selection according to sample availability will further decrease risks of test thus saving money and time and effort. 


\section{REFERENCES}

De Boer, H; Maat, R; AjiKadarmo, D; Widodo, T., Kloosterman, D; and Kala, J. (2018 a) DNA identification of human remains in Disaster Victim Identification (DVI): An efficient sampling method for muscle, bone, bone marrow and teeth, Forensic Science International; 289:253-259.

De Boer, H; Blau, S; Delabarde, T; and Hackman, L. (2018 b) The role of forensic anthropology in disaster victim identification (DVI): recent developments and future prospects. Forensic Sciences Research; 2096-1790:2471-1411.

Ferreira, G; Ferreira, G; Paula, A; Nogueira, C; Oliveira, S; and Moraes, A.V. (2013) Cartilage and phalanges from hallux: Alternative sources of samples for DNA typing in disaster victim identification (DVI). A comarative study, Forensic Science International: Genetics Supplement Series; 4: 366-367.

Interpol Disaster Victim Identification Guide. (2018) available from; file://C:/Users/GigaByte/Downloads/18Y1344\%20E\%20DVI_G uide\%20(4).pdf. Kaneko, Y; Ohira, H; Tsuda, Y; and Yamada, Y. (2015) Comparison of hard tissues that are useful for DNA analysis in forensic autopsy, Legal Medicine Journal ;17):547552 .

Meyer, J. (2003) The Kaprun cable car fire disaster--aspects of forensic organisation following a mass fatality with 155 victims, Forensic Science International;138 (1-3):1-7.

Montelius, K; and Lindblom, B. (2012) DNA analysis in disaster victim identification, Forensic Science Medical Patholology; 8 (2): 140 147.

Mundorff, Z; Bartelink, J; and Mar-Cash, E. (2009) DNA preservation in skeletal elements from the World Trade Center disaster: recommendations for mass fatality management, Journal of Forensic Sciences; 54 (4): 739-745. 
Pagana, F; Limb, C; Keglovicb, M; and McNevina, D. (2012) Comparison of DNA extraction methods for identification of human remains, Australian Journal of Forensic Sciences;44(2):117-127

Wheeler, A; Czado, N; Gangitano, D; Turnbough, M; and Hughes-Stamm, S. (2017) Comparison of DNA yield and STR success rates from different tissues in embalmed bodies, International Journal of Legal Medicine; 131(1):61-66.

Weedn, W; and Baum, J. (2011) DNA identification in mass fatality incidents, American Journal of Forensic Medical Pathololgy; 32(4):393-7.

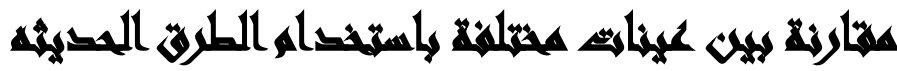

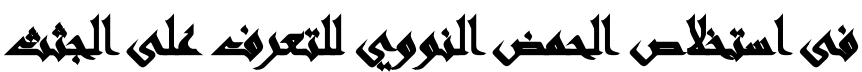

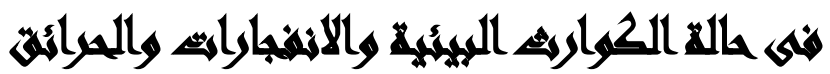

$[r]$

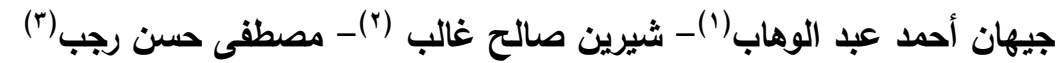

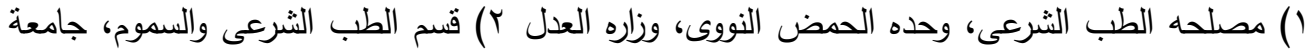

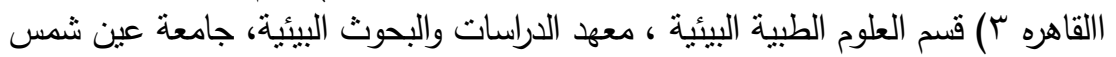

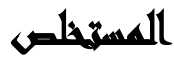

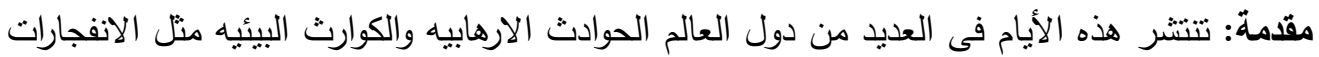

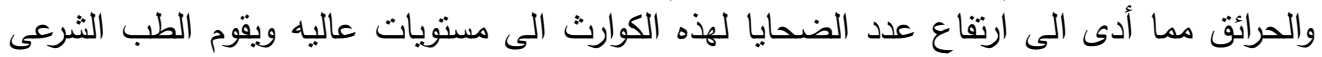

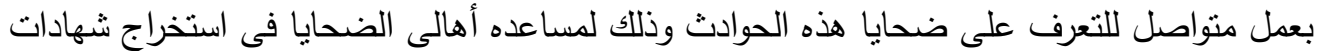

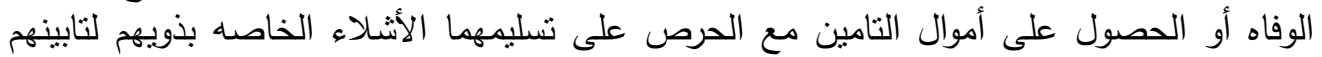
ودفنهم بطريقه مناسبه.

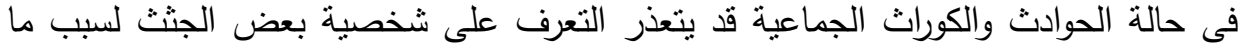

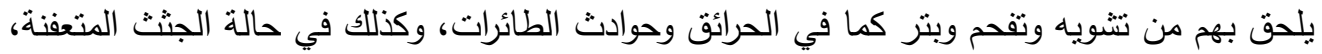

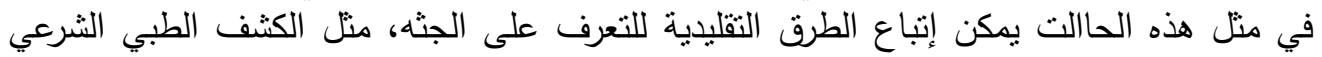

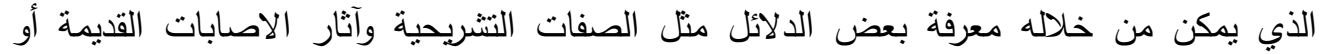

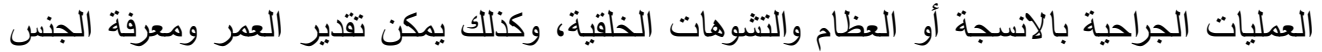


من خلال فحص العظام، ولكن هذه الطريقة قاصرة و معيبة لاسباب عدة ، منها تقحم الجثث وتشوهها

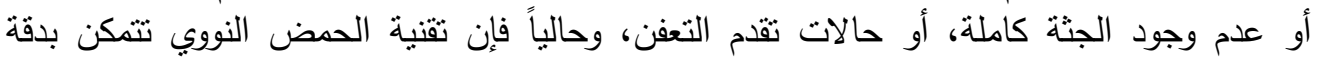

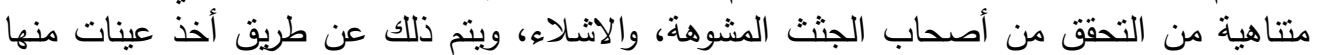

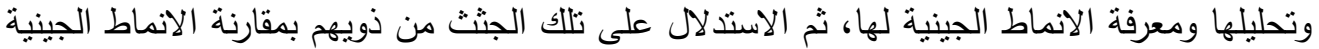

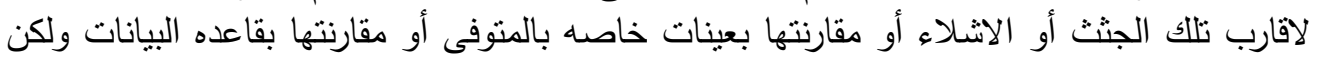

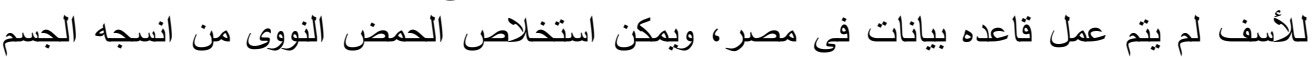

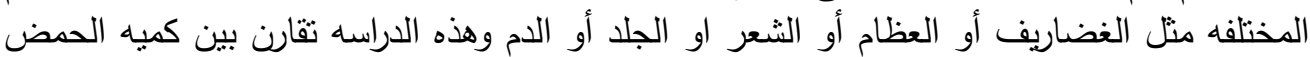
النووى المستخلص من أنسجة مختلفه.

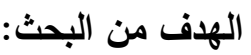

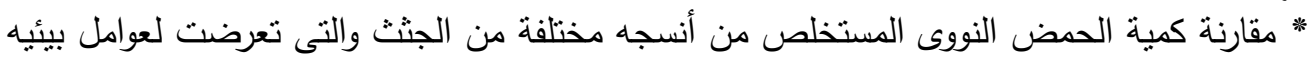

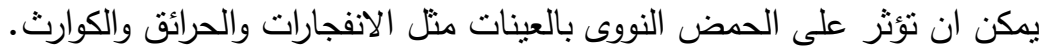

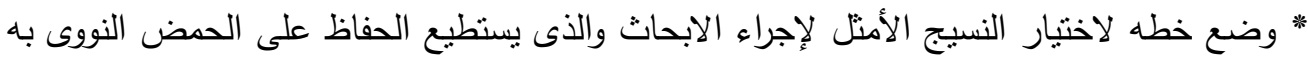

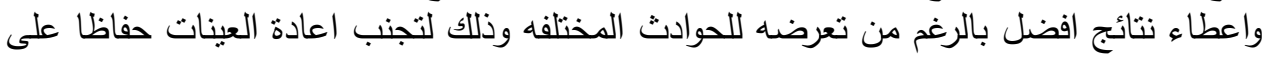

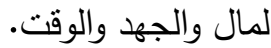

الحالات وطرق البحث: أجريت هذه الدراسة المقطعية بمصلحه الطب الثرعى بالسيده زينب بالقاهره

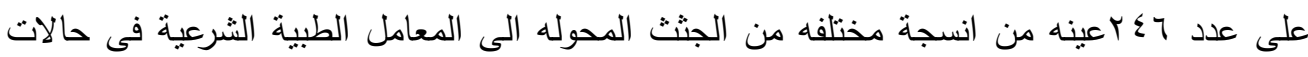

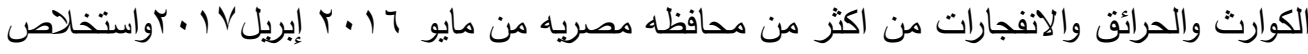

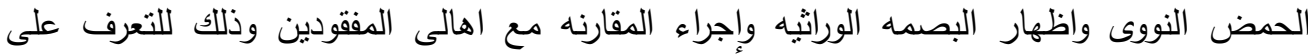

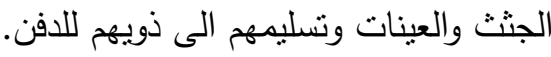

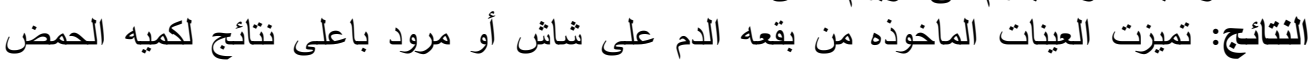

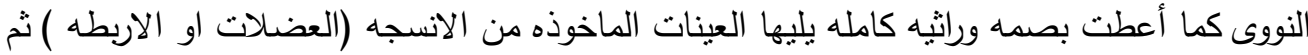

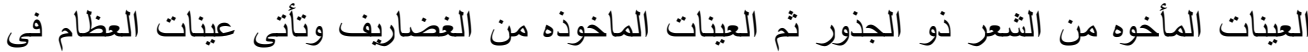

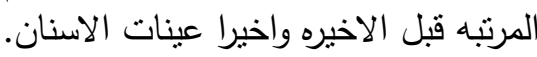

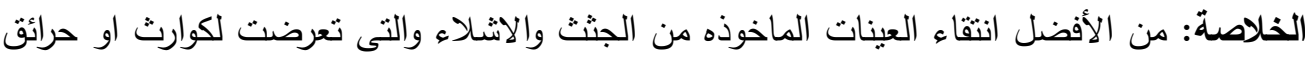

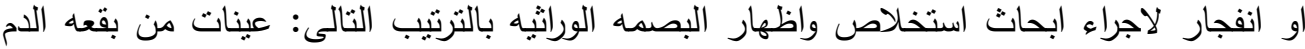

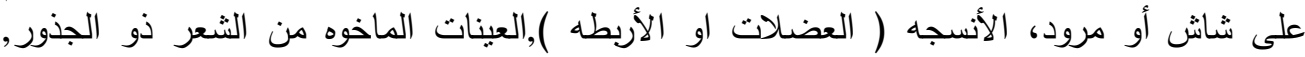

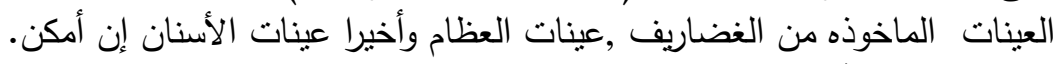

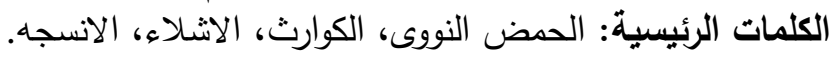

